\title{
Induction of Neutral Lipid-Containing Granules by Staphylococcal Lipase from Clinical Isolates
}

\author{
Shigeki Kamitani ${ }^{1,2 *}$, Masami Miyake ${ }^{2,3}$, Michiko Hatano ${ }^{2}$, Takashi Yutsudo ${ }^{4}$, Wakio Minamide ${ }^{4}$, \\ Iwao Kato ${ }^{2}$, Masatoshi Noda ${ }^{2}$ \\ ${ }^{1}$ Department of Clinical Nutrition, Faculty of Comprehensive Rehabilitations, Osaka Prefecture University, Habikino, Osaka, Japan \\ ${ }^{2}$ Department of Molecular Infectiology, Graduate School of Medicine, Chiba University, Chiba, Japan \\ ${ }^{3}$ Department of Veterinary Environmental Sciences, Graduate School of Life and Environmental Sciences, Osaka Prefecture University, Izumisano, Osaka, Japan \\ ${ }^{4}$ Shionogi and Co., Ltd., Toyonaka, Osaka, Japan
}

Received: April 16, 2014; Accepted: May 20, 2014; Published: May 21, 2014

*Corresponding author: Shigeki Kamitani, Department of Clinical Nutrition, Faculty of Comprehensive Rehabilitations, Osaka Prefecture University, 3-7-30, Habikino, Habikino-shi, Osaka 583-8555, Japan, Phone: +81-72-950-2837, Fax: +81-72-950-2127, E-mail: skami@rehab.osakafu-u.ac.jp

\begin{abstract}
Culture supernatant of Staphylococcus aureus, isolated from a patient who died after surgery induced granulation in several cultured cell lines of human and animal origin. Histochemical study revealed that the granules contained neutral lipid. A granuleinducing substance was partially purified by DEAE- TOYOPEARL column chromatography. The final preparation revealed two major proteins ( 45 and $43 \mathrm{kDa}$ ) in SDS-PAGE, both of which were cytopathic. Sequencing of the N-terminal and internal amino acids of both proteins demonstrated that the $45-\mathrm{kDa}$ protein is a mature staphylococcal lipase and the $43-\mathrm{kDa}$ protein is a truncated form of this mature lipase. Recombinant lipase also showed cytopathicity. A mutant lipase, constructed by substitution of a serine residue in the catalytic triad of the lipase into alanine, lost both cytopathic and enzymatic activities, indicating that the lipase activity is critical for the cytopathicity. Our results indicate that staphylococcal lipase induces granule formation presumably by impairing lipid metabolism of the cultured cells. Our results raise the possibility that the lipase may play a role in bacterial infection by affecting the cellular metabolism of host cells.
\end{abstract}

Keywords: Staphylococcus aureus; Lipase; Cytopathicity; Recombinant; Methicillin-Resistant S. aureus (MRSA); Granule

\section{Introduction}

Staphylococcus aureus is an important pathogen causing a wide range of infections in humans and other animals. Possible virulence factors, including various proteinaceous toxins and enzymes, and their roles in the bacterial infection have been the main foci of investigations [1,2]. Among them, alpha-toxin, which is one of the major virulence determinants of microorganisms, and enterotoxins have been extensively examined and characterized biochemically and biologically [2]. However, a precise understanding of the enzymes secreted by $S$. aureus upon bacterial infection has yet to be obtained.

Staphylococcal lipases have been purified from several Staphylococcus spp. and their enzymatic properties have been well documented [3-6]. Molecular biological studies and threedimensional structure analysis revealed that amino acid residues
Ser-Asp-His form the active center of the catalytic activity $[3,7]$ and the serine of this catalytic triad is part of the pentapeptide Gly-X-Ser-X-Gly, which is extremely conserved among serine hydrolases [7]. Staphylococcal lipase-2 of S. aureus (SAL-2) encoded by the geh gene is produced as a 76-kDa preproprotein, which is processed to a $43-45-\mathrm{kDa}$ mature protein extracellularly [8].

The association of lipase with bacterial pathogenesis has been described as follows. The enzymatic digestion of lipids can benefit bacterial growth [9], and the resultant free fatty acids may impair several immune system components [10-15]. The enzyme itself may interfere with human leukocyte function $[16,17]$. Various types of staphylococcal lipase has been highly purified [4-6,18-22], but their biological role remained unclear, mainly because a small amount of detergent contaminated in the purified preparation might have affected their observations.

In this study, we identified novel cytopathicity in culture supernatant of $S$. aureus clinical isolates. This cytopathicity was shown to be caused by staphylococcal lipase, and the active site of the lipase was shown to be necessary for both enzymatic and cytopathic activities.

\section{Materials and Methods}

\section{Bacterial culture}

A methicillin-resistant Staphylococcus aureus (MRSA) strain, 10-123, was isolated from a stool of a patient suffering from severe diarrhea after post-operative antibiotic treatment, who eventually died. MRSA strains No. 1, 2, 3, 4, 5, 6, and MethicillinSensitive S. aureus (MSSA) strains No. 1, 2, 3, 4 were also clinically isolated. The stock cultures kept at $-80^{\circ} \mathrm{C}$ were inoculated onto nutrient agar (Nissui Pharmaceutical Co., Ltd.,Tokyo, Japan) and incubated overnight. A single colony on the agar plate was picked up, inoculated into $5 \mathrm{ml}$ of nutrient broth (Nissui), and cultured overnight with shaking. A portion of $1.5 \mathrm{ml}$ of the seed culture was then inoculated into $150 \mathrm{ml}$ of nutrient broth in a 500-ml flask and the flask was incubated at $37^{\circ} \mathrm{C}$ for $24 \mathrm{~h}$ with shaking. To purify a cytopathic substance, $50 \mathrm{ml}$ of the culture was 
inoculated into $1.5 \mathrm{~L}$ of nutrient broth in a 5-L flask and incubated $24 \mathrm{~h}$ at $37^{\circ} \mathrm{C}$ with shaking. For the lipase and cytopathicity assays, the bacterial culture was centrifuged at $10,000 \mathrm{x}$ g for $20 \mathrm{~min}$, and filtered through cellulose acetate filters $(0.22 \mu \mathrm{m}$ pore size, Sartorius AG, Goettingen, Germany). The culture filtrate was stored at $-20^{\circ} \mathrm{C}$ until use.

\section{Characterization of the strain}

The strain MRSA 10-123 was characterized as follows. Many kinds of drug sensitivity including for oxacillin were tested by MIC determination, disk diffusion and agar screen methods, respectively. Hemolytic activity by $\alpha$-toxin was detected on rabbit blood plate [23]. Producibility and typing of staphylococcal enterotoxin, TSST-1 and coagulase were investigated by using, respectively, SET-RPLA, TST-RPLA and Coagulase Antisera (Seiken, Tokyo, Japan). Specific primers for the amplification of toxA and lukS genes were designed:

5'-CAT TGC TGG TCA ATA TAG AG-3' and 5'-GTT GGG CTC TCT AAA ATT GT-3' (for toxA), and 5' - CTA CAA CTT TAT CTG TGA GC-3' and 5'-TTA TAT TGG AAT GGC CAT CG-3' (for lukS). The mecA gene was identified according to Murakami et al. [24]. The nucA gene was detected by the method of Brakstad et al. [25]. Detection of genes for enterotoxins and toxic shock syndrome toxin 1 was performed on the basis of the method of Johnson et al. [26].

\section{Cytopathicity assay}

$U^{r}$-1 human embryonic clonal cells [27], Chinese hamster ovary (CHO) cells, were maintained with Eagle's minimum essential medium (MEM) supplemented with $10 \%$ newborn calf serum throughout the experiments. The cells were inoculated at $1.5 \times 10^{3}$ cells/well (150 ml/well) in a 96-well plate. A total of $50 \mu \mathrm{l}$ of the supernatant or chromatography effluents was added into the well and the mixture was incubated at $37^{\circ} \mathrm{C}$ for $24 \mathrm{~h}$. Morphological changes of UV ${ }^{\mathrm{r}}-1$ cells were examined under phase-contrast light microscopy.

\section{Lipase assay}

Lipase activities in the supernatant were determined with Lipase Kit S (Dainippon Pharmaceutical, Co. Ltd., Osaka, Japan) with a colorimetric substrate. The supernatant was serially diluted with a dilution buffer supplied in the kit and subjected to the lipase assay in according with the manufacturer's instructions. The reaction was terminated with termination buffer, and optical density at $412 \mathrm{~nm}\left(\mathrm{OD}_{412}\right)$ of the reaction mixtures was determined. One unit was defined as the activity that shows an increase of $\mathrm{OD}_{412}$ of 1.0 for $30 \mathrm{~min}$ at $30^{\circ} \mathrm{C}$. The experiments were performed at least three times and the data are representative of three experiments and each point represents the mean of duplicate measurements.

\section{Purification of cytopathic substance}

MRSA10-123 culture supernatant (10 L) was precipitated by adding $75 \mathrm{mM} \mathrm{ZnCl}_{2}$ and centrifuged at 8,000 x g for $15 \mathrm{~min}$ at $4^{\circ} \mathrm{C}$. The precipitate was dissolved in $2 \mathrm{~L}$ of $0.4 \mathrm{M} \mathrm{Na}_{2} \mathrm{HPO}_{4}$ and centrifuged at 8,000 x g for $15 \mathrm{~min}$. The supernatant was dialyzed against $20 \mathrm{~L}$ of TEN buffer (20 mM Tris-HCl pH 7.5, 1 mM EDTA, $1 \mathrm{mM} \mathrm{NaN}_{3}$ ) overnight. The dialysate was applied to a DEAETOYOPEARL column $(3 \times 90 \mathrm{~cm})$. After washing away unbound materials with TEN buffer, cytopathic fractions were eluted with TEN buffer containing $0.5 \mathrm{M} \mathrm{NaCl}$. The effluent was collected and dialyzed against TEN buffer, and re-applied to DEAE-TOYOPEARL. Elution was performed with TEN buffer containing a 0-0.3 M $\mathrm{NaCl}$ gradient. The cytopathic fractions were concentrated with ultrafiltration membrane (PM-10 membrane, Amicon) to a final volume of $1.0 \mathrm{ml}$. Sodium dodecylsulfate-polyacrylamide gel electrophoresis (SDS-PAGE) of the partially purified preparation revealed two major protein bands with molecular masses of 43 and $45 \mathrm{kDa}$. In order to identify the proteins, $\mathrm{ZnCl}_{2}$-imidazole staining was performed [28] and then recovery was carried out by electroelution (The Centrilutor Micro-Electroelutor, Amicon).

\section{Analysis of amino acid sequence}

$\mathrm{N}$-terminal sequences of the 43 -and 45 -kDa proteins were determined with a protein sequencer (PSQ-1, Shimadzu, Kyoto, Japan) after electro blotting onto a PVDF membrane (Transblot, BioRad) by the method of Towbin [29]. To determine the internal sequences, the 43 -and $45-\mathrm{kDa}$ proteins extracted from the polyacrylamide gel were digested with lysyl-endopeptidase (LEP; Wako, Tokyo, Japan) [30]. Peptides purified by reversephase chromatography (LC-6A, Shimadzu, Kyoto, Japan; ODSHG-5 column, Nomura Chemical, Tokyo, Japan) were sequenced.

\section{Preparation of the recombinant lipase and mutant lipase}

MRSA10-123 was grown with shaking overnight at $37^{\circ} \mathrm{C}$ in $5 \mathrm{ml}$ of tryptic soy broth and recovered by centrifugation. After washing, the chromosomal DNA was prepared as described previously [31]. For cloning of the mature part of the lipase gene geh [32], PCR primers with BamHI or EcoRI sites were used: 5'-CT GGA TCC AAA GCG AAT CAA GTA CAA CCA CTT A-3' (LIP-S1) and 5'-GC GAA TCC TTA ACT TGC TTT CAA TTG TGT TCC TT-3' (LIP-A1). A 1,188-bp DNA fragment was amplified by PCR and digested with BamHI and EcoRI. The digested fragment was cloned into pGEX-2T, a glutathione-S-transferase (GST) fusion vector plasmid (Pharmacia, Sweden). BL21 (DE3) cells transformed with $p G H 26$ (a plasmid with an insert encoding the GST-lipase fusion protein) were incubated until the early log phase and the recombinant lipase was induced with $0.1 \mathrm{mM}$ IPTG. After 3-5 h, the cells were collected by centrifugation and lysed by sonication in PBS-1\% Triton X-100. After centrifugation and filtration, the recombinant GST-lipase fusion protein was absorbed to a Glutathione Sepharose 4B column, and cleaved by using thrombin at $4^{\circ} \mathrm{C}$ overnight. Recombinant lipase was eluted with $0.5 \mathrm{M} \mathrm{NaCl}-50 \mathrm{mM}$ Tris $\mathrm{HCl}, \mathrm{pH}$ 8.0. The plasmid expressing the recombinant mutant lipase was constructed by site-directed mutagenesis. Mutated primers containing a SphI site are: 5'-CCA CCC ATA GCA TGC CCT AC-3' (LIP-MA1) and 5'-GTA GGG CAT GCT ATG GGT GG-3' (LIP-MS1). A 362-bp DNA fragment for LIP-S1/ LIP-MA1 and an 850-bp DNA fragment for LIP-MS1/ LIP-A1 were amplified and each PCR product was digested with SphI. These two fragments were ligated into pGEX-2T. The recombinant mutant lipase was purified by the same method. 


\section{Preparation of anti-lipase antibody}

BALB/C female mice were injected with either 5 or $25 \mu \mathrm{g}$ of the purified cytopathic fraction. Several injections were performed over 2 months. The serum was recovered after 3 months and the anti-recombinant lipase titer was checked. The anti-recombinant lipase antibody raised in rabbit (Japanese White) was purified by protein A-coupled Sepharose column chromatography 3 months after immunization. A total of $5 \mathrm{mg}$ of protein A (EY Laboratories, Inc., San Mateo, CA) was coupled with a pre-packed HiTrap NHS-activated (Pharmacia Biotech) column according to the manufacturer's instructions. The column was equilibrated with PBS before use and $1 \mathrm{ml}$ of rabbit serum (anti-recombinant lipase serum or pre-immune serum) was applied to it. After the column was washed with $5 \mathrm{ml}$ of PBS, the bound antibody was eluted with $3 \mathrm{ml}$ of $0.2 \mathrm{M}$ glycine - $\mathrm{HCl}, \mathrm{pH} 2.8-0.5 \mathrm{M} \mathrm{NaCl}$. The effluent was neutralized with $1 \mathrm{M}$ Tris- $\mathrm{HCl}, \mathrm{pH} 8.0$, immediately, concentrated by ultrafiltration and dialyzed against PBS.

\section{Western blot analysis}

The specificity of the antibodies purified by protein A-coupled affinity chromatography was examined by Western blot analysis. The effluent from DEAE-TOYOPEARL chromatography or the recombinant lipase was run in an SDS-PAGE gel (12\%) and the separated proteins were transferred onto a PVDF membrane [29]. After blocking with $3 \%$ bovine serum albumin and $2 \%$ skim milk in washing buffer (PBS-0.1\% Tween 20), the membrane was incubated for $2 \mathrm{~h}$ with $5 \mu \mathrm{g}$ of either affinity-purified antirecombinant lipase antibody or pre-immune antibody per $\mathrm{ml}$ of washing buffer. The membrane was probed with peroxidaseconjugated anti- rabbit IgG antibody (Organon Teknika Corp., West Chester, PA) for $2 \mathrm{~h}$ at room temperature, followed by enzyme detection with ECL Western blotting detection reagents (Amersham International plc, Buckinghamshire, England).

\section{Neutralization study}

A total of $100 \mu \mathrm{l}$ of the supernatant from MRSA 10-123 was incubated for $30 \mathrm{~min}$ at room temperature with $100 \mu \mathrm{l}$ of affinity purified anti-recombinant lipase antibody or antibody from preimmune serum. The mixture was subjected to the cytopathicity assay. Briefly, $5 \times 10^{3}$ cells were treated with the mixture and incubated. The experiments were performed three times and the data are representative of three experiments and each point represents the mean of duplicate measurements.

\section{Determination of protein concentration}

Protein concentration was determined by the Bradford method [33] (Protein Assay, BioRad Laboratories, Hercules, CA). Bovine serum albumin served as a standard.

\section{Results}

\section{General properties of $S$. aureus MRSA (methicillin- resistant $S$, aureus) 10-123 strain}

MRSA 10-123 showed TSST-1, enterotoxin C and type II coagulase activities, but not $\alpha$-toxin and $\beta$-lactamase activities, by bacteriological examinations. Genes of nucA, mecA, sec, luk $\mathrm{S}$ and toxA were detected in MRSA 10-123 by PCR (data not shown). The filtered supernatant from overnight culture of MRSA 10-123 was examined for cytotoxicity to UV ${ }^{\mathrm{r}}-1$ [27] and $\mathrm{CHO}$ cells. Both cells were severely damaged by the supernatant at high concentration (4- to 16-fold dilution), and then lysed by $24 \mathrm{~h}$ after incubation. However, at low concentration (more than 32-fold dilution), intracellular granules accumulated inside of cells. Oily vesicles accumulated in UV $\mathrm{UV}^{\mathrm{r}}-1$ cells after 12-h incubation with the supernatant (Figure 1B) in contrast to the case for PBS (Figure 1A). After 24-h incubation, the cells had become round and detached from the plate. Histochemical examination by Sudan III staining [34] showed that neutral lipid was present in the vesicles (Figure 1C). The morphological changes of the cells treated with the supernatant were caused by the formation of neutral lipid vesicles. The cytopathic substrate of the supernatant was heat-stable because the supernatant did not lose cytopathicity after heating at $80^{\circ} \mathrm{C}$ for $30 \mathrm{~min}$ (data not shown). Hereafter, this vesicle formation was regarded as the source of cytopathicity in this study.

\section{The cytopathic substance is a staphylococcal lipase}

Next, we attempted to purify and identify the cytopathic substance in the bacterial culture supernatant. Cytopathicity was recognized in the fractions eluted with $0.30-0.35 \mathrm{M} \mathrm{NaCl}$ by DEAE-TOYOPEARL chromatography (Figure 2A). SDSPAGE revealed that the fractions included two major proteins with molecular masses of 43 and $45 \mathrm{kDa}$ (Figure 2B). The protein bands visualized by $\mathrm{ZnCl}_{2}$-imidazole staining were then recovered by electroelution and tested for cytopathicity. Both 43- and 45-kDa proteins showed cytopathicity to UV ${ }^{\mathrm{r}}-1$ cells. The $45 \mathrm{kDa}$ protein was digested with lysyl-endopeptidase. Two peptides separated by high- performance liquid chromatography (HPLC) were then sequenced by using a protein sequencer. The amino acid sequence of one peptide was identical to the N-terminal sequence of Staphylococcus aureus lipase-2 (SAL-2), and the sequence from the other peptide corresponded to the internal sequence of the same lipase (Figure 3), indicating that

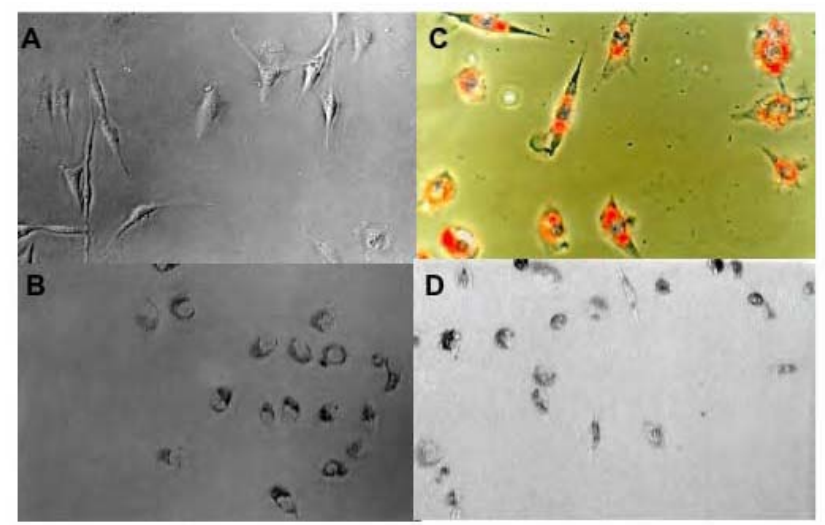

Figure 1: Cytopathicity by the supernatant of MRSA 10-123 and by recombinant lipase to the human embryonic UV $\mathrm{UV}^{\mathrm{r}}-1$ cells. Cells were passaged at $1.5 \mathrm{X} 10^{3}$ cells/well. A total of $50 \mu \mathrm{l}$ of either PBS (A) or the supernatant (B) was added to the well. After 24-h incubation, the cell viability was examined by light microscopy. Furthermore, the cells treated with the supernatant were stained for neutral fat with Sudan III (C). $\mathrm{UV}^{\mathrm{r}}-1$ cells were treated with $50 \mu \mathrm{l}$ of recombinant lipase (D). 
the $45-\mathrm{kDa}$ cytopathic protein is a lipase. The $43-\mathrm{kDa}$ protein was also subjected to the digestion by a proteinase and peptide sequencing. The $\mathrm{N}$-terminal and internal amino acid sequences of the 43-kDa polypeptide were identical to those of the 45$\mathrm{kDa}$ protein. As previously reported the staphylococcal lipase is secreted into the culture supernatant as a $76-\mathrm{kDa}$ proenzyme and activated extracellularly to produce a $45-\mathrm{kDa}$ mature protein [8]. These factors indicates that the $45-\mathrm{kDa}$ protein identified as a cytopathic substance is staphylococcal lipase and that the 43$\mathrm{kDa}$ cytopathic protein is presumably generated by degradation of the $45-\mathrm{kDa}$ lipase by limited proteolysis at its C-terminal portion because the $\mathrm{N}$-terminal and internal sequences of the two proteins were shown to be identical.

\section{Recombinant staphylococcal lipase is cytopathic}

To obtain a further confirmation that the cytopathic substance in the supernatant was staphylococcal lipase, the gene encoding the lipase, geh, from MRSA 10-123 was cloned and its gene

\section{A}

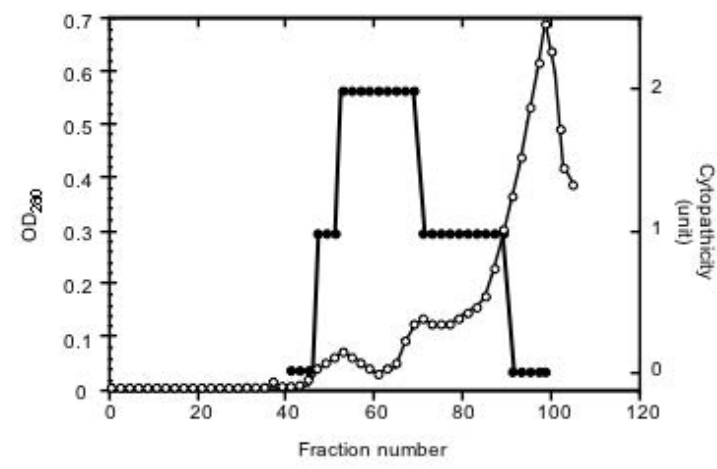

B

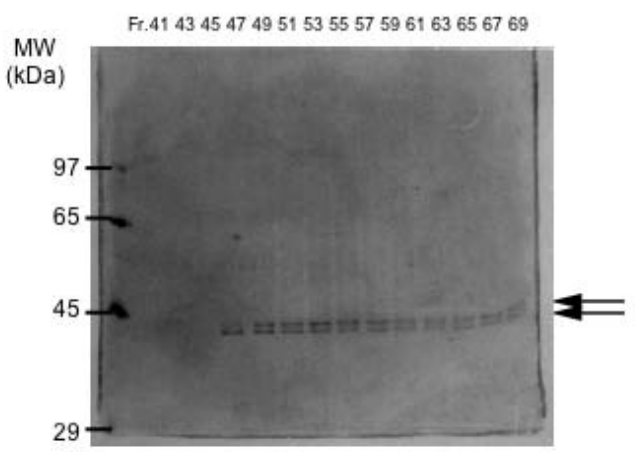

Figure 2: The elution profile of DEAE-TOYOPEARL chromatography and the migration profile on SDS- PAGE. (A) DEAE-TOYOPEARL chromatography was performed. The cytopathicity was recognized in the fractions eluted with 0.3 to $0.35 \mathrm{M} \mathrm{NaCl}$. The cytopathicity is described in units; the number of units in fractions is numerically equal to the dilution at $\mathrm{CD}_{50}$. Protein concentration was revealed by $\mathrm{OD}_{280}$ (open circle) and the cytopathicity was scored (closed circle). (B) The fractions with cytopathicity were analyzed by $10 \%$ SDS-PAGE.

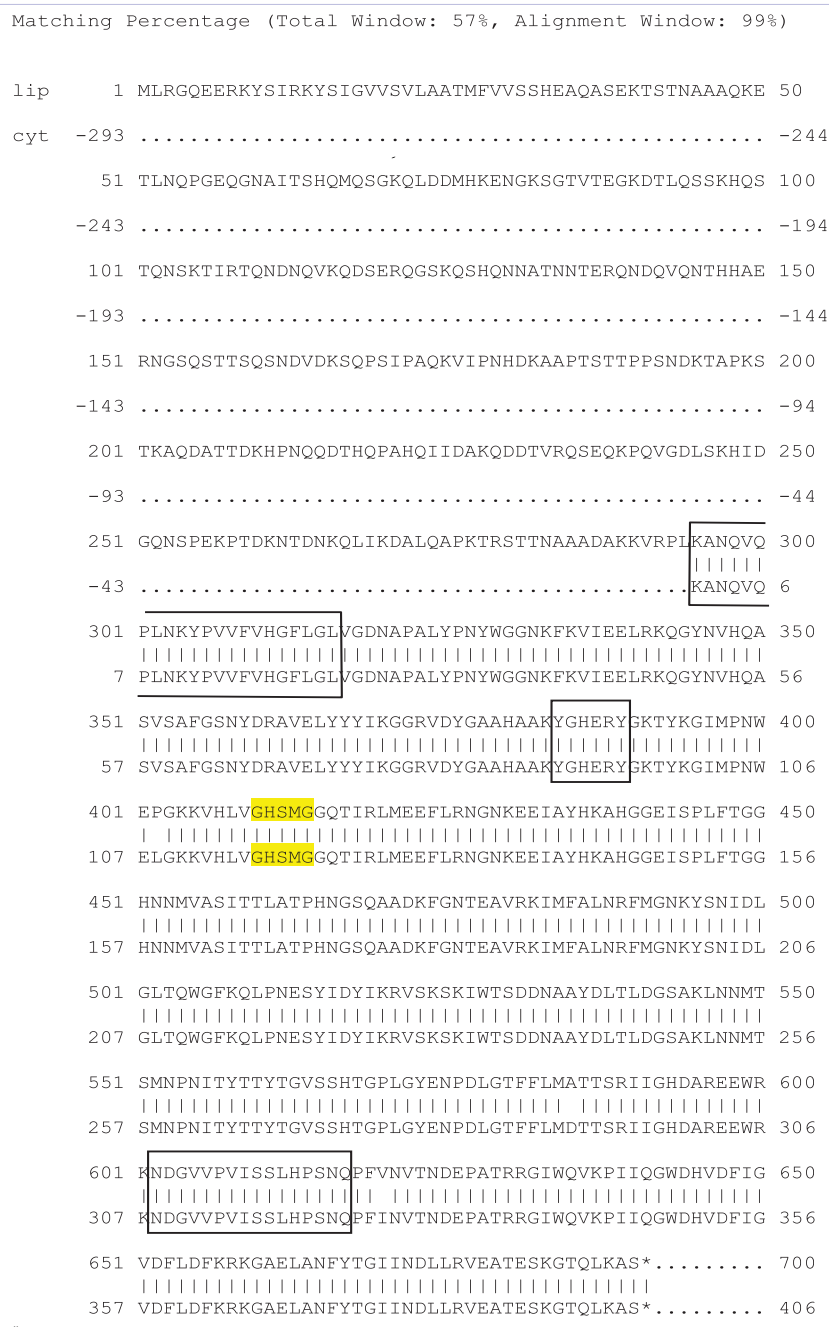

Figure 3: Homology search for the cytopathic substrate versus staphylococcal lipase. Homology search was performed by using Blast. Upper sequence is deduced from the geh gene (Genbank accession number: M12715). Lower sequence is from DNA sequencing of the recombinant lipase. Three boxes indicate the amino acid sequences identified by the peptide sequencing analysis of the cytotoxin and the amino acid sequence highlighted with yellow indicates the consensus sequence of lipase catalytic domain.

product was expressed in Escherichia coli as a glutathione-Stransferase (GST) fusion protein. The fusion protein was purified with a glutathione-Sepharose 4B column, and its GST portion was cleaved by thrombin digestion. The recombinant lipase induced morphological changes of $\mathrm{UV}^{\mathrm{r}}-1$ cells as well as $45-$ to $43-\mathrm{kDa}$ cytopathic protein from MRSA 10-123 (Table 1; Figure 1D). Next, we examined whether the cytopathicity in the supernatant was neutralized by the rabbit polyclonal antibody against the recombinant lipase. A total of $40 \mu \mathrm{g}$ of the antibody completely neutralized the cytopathicity of the supernatant, whereas the same amount of affinity-purified antibody from pre-immune serum failed to do so (data not shown).

These results suggested that the cytopathicity in the supernatant mostly involved the lipase. The specificity of this 
antibody against staphylococcal lipase was confirmed by western blotting (Figure 4). In addition, mouse polyclonal anti-lipase antibodies obtained upon immunization with purified native lipase completely inhibited the cytopathicity (Figure 5), whereas pre-immune serum did not.

\section{Lipase activity was essential for the cytopathicity}

In general, the catalytic site of lipase consists of Ser-AspHis amino acid residues. To examine whether the lipase activity was essential for the cytopathicity, the serine residue in the highly conserved pentapeptide sequence GXSXG was replaced with alanine by site-directed mutagenesis of the wild-type recombinant lipase. As shown in (Table 1), the mutant lipase lost the lipase activity. In contrast, the wild-type recombinant lipase and purified staphylococcal lipase were more active than human pancreatic lipase or Rhizopus lipase. The mutant lipase showed no cytopathicity to the UV $\mathrm{V}^{\mathrm{r}}-1$ cells (Table 1 ), whereas Rhizopus lipase and human pancreatic lipase were slightly cytopathic.

Table 1: Comparison of the cytopathicity and the lipase activity of various types of lipases.

\begin{tabular}{|c|c|c|}
\hline & $\mathrm{CD}_{50}(\mathrm{ng} / \mu \mathrm{l})$ & Lipase Activity (units/ug) \\
\hline Staphylococcal lipase & 0.1 & n.t. ${ }^{a}$ \\
\hline r-lipase ${ }^{b}$ & 0.068 & 4800 \\
\hline r-m-lipase ${ }^{c}$ & $>200$ & $<10$ \\
\hline Rhizopus lipase & 63 & 800 \\
\hline human pancreatic lipase & 73 & 300 \\
\hline
\end{tabular}

n.t ${ }^{a}$.: not tested, $r$-lipase ${ }^{b}$ : the recombinant lipase, r-m-lipase $c$ : the recombinant mutant lipase

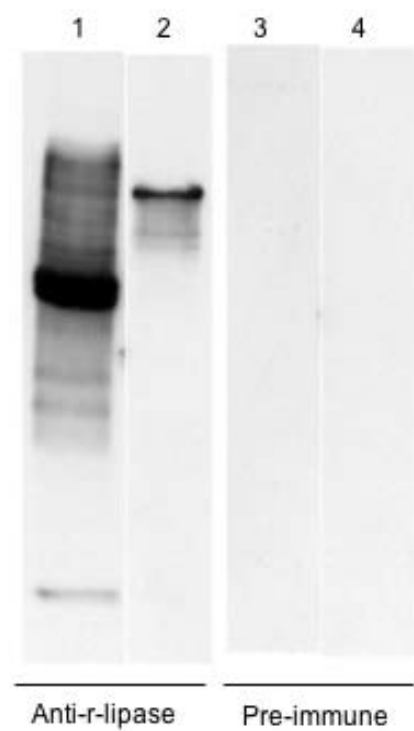

Figure 4: The specificity of the antibody against staphylococcal lipase: Anti-recombinant lipase antibody raised in rabbit (Japanese White) was purified by protein A-coupled Sepharose column chromatography. Western blotting was performed with the anti-lipase antibody (lanes 1 , 2) or pre-immune sera (lanes 3,4) against the supernatant from MRSA 10-123 strain (lanes 1,3) and the recombinant GST-lipase (lanes 2, 4).

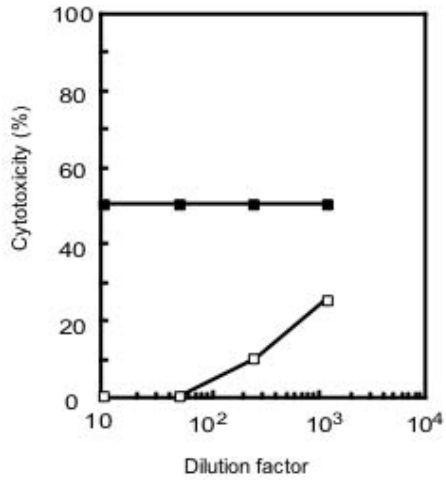

Figure 5: Neutralization of the cytopathicity with anti-lipase antibody: The cytopathicity assay was performed as described in Material and Methods. The recombinant lipase was previously mixed with either normal serum or anti-lipase antibody for neutralization assay. Neutralizing effects of normal serum (closed square) and anti- lipase antibody (open square) are shown. The experiments were performed at least three times and the data are representative of three experiments and each point represents the mean of duplicate measurements.

These results indicate that the cytopathicity is identical to the lipase activity.

\section{Lipase activity in the supernatant from $S$. aureus clinical isolates}

To investigate the lipase productivity of various types of $S$. aureus strain, ten clinical isolates including four strains of methicillin-sensitive $S$. aureus (MSSA) and six strains of MRSA were examined for the lipase activity of each supernatant (Table 2). Three strains of the four MSSA and one strain of the seven MRSA showed lower lipase activities ( $<3$ units); in contrast, one strain of the four MSSA and six strains including MRSA 10-123 of the seven MRSA had higher lipase activities ( $>3$ units). These results indicate that $S$. aureus strains were classified into two different groups possessing high or low lipase activities.

\section{Discussion}

We identified granule-inducing activity of the staphylococcal culture supernatant on human and animal cell lines. Our observation clearly demonstrated that cytopathicity in the supernatant from MRSA 10-123 was caused by the staphylococcal lipase. Staphylococcal lipase has both chemotactic and chemokinetic properties for human granulocytes [35] and causes monophasic aggregation accompanied by the release of lactoferrin [17]. Moreover, lipase interferes with human granulocyte phagocytic killing of Staphylococcus aureus but not Staphylococcus pneumoniae or Streptococcus agalactioae $[16,36,37]$. Staphylococcal strains from deep infections produce more lipase than strains from superficial locations [38]. Such strains produce lipases in excess of the amounts necessary to elicit an aggregation response in granulocytes. In this study, the staphylococcal lipase was purified without using a detergent such as Triton X-100. Therefore, the biological effect of staphylococcal lipase was precisely confirmed. Others reported that patients with bacterial endocarditis showed positive reactivity with antibody 
Table 2: Lipase activity in the culture supernatant from S. aureus clinical isolates.

\begin{tabular}{|c|c|}
\hline Strain & Lipase Activity (units/ $\boldsymbol{\mu g}$ ) \\
\hline MSSA & $<1$ \\
\hline MSSA1 & $<1$ \\
\hline MSSA2 & 2.9 \\
\hline MSSA3 & $>64$ \\
\hline MSSA4 & \\
\hline MRSA & 5.5 \\
\hline MRSA1 & 13 \\
\hline MRSA2 & 5 \\
\hline MRSA3 & 20 \\
\hline MRSA4 & 15 \\
\hline MRSA5 & 2.3 \\
\hline MRSA6 & 7 \\
\hline MRSA10-123 & \\
\hline
\end{tabular}

to staphylococcal lipase or a significant change in antibody titer [39]. These reports suggest that lipase serves as a virulence factor in severe infection of $S$. aureus including septicemia. Our data also showed that there are two groups of $S$. aureus with high and low lipase activities. More recently, in an intraperitoneal challenge mouse model of $S$. aureus, peritoneal abscess formation was reduced by the lipase-deleted mutant [40]. Taking these findings together, staphylococcal lipase may have a role in determining the survival of $S$. aureus in lesions and the cytopathicity may be involved in the pathogenesis of staphylococcal disease.

\section{Acknowledgment}

We thank Dr. Atsushi Morita for immunization to mice and rabbits and Ms. Emi Utsuno for her technical assistance. Thanks are also due to Dr. Joel Moss for his critical reading of this manuscript. This work was supported by a Grant-in-Aid of Scientific Research (06454203) from the Ministry of Education, Science and Culture of Japan, by the Uehara Memorial Foundation and by Chiba University.

\section{References}

1. Chavakis T, Preissner KT, Herrmann M (2007) The anti-inflammatory activities of Staphylococcus aureus. Trends Immunol 28(9): 408-418.

2. Zecconi A, Scali F (2013) Staphylococcus aureus virulence factors in evasion from innate immune defenses in human and animal diseases. Immunol Lett 150(1-2): 12-22.

3. Rosenstein R, Gotz F (2000) Staphylococcal lipases: biochemical and molecular characterization. Biochimie 82(11): 1005-1014.

4. Sayari A, Agrebi N, Jaoua S, Gargouri Y (2001) Biochemical and molecular characterization of Staphylococcus simulans lipase. Biochimie 83(9): 863871

5. Mosbah H, Sayari A, Mejdoub H, Dhouib H, Gargouri Y (2005) Biochemical and molecular characterization of Staphylococcus xylosus lipase. Biochim Biophys Acta. 1723(1-3): 282-291.

6. Xie W, Khosasih V, Suwanto A, Kim HK (2012) Characterization of lipases from Staphylococcus aureus and Staphylococcus epidermidis isolated from human facial sebaceous skin. J Microbiol Biotechnol 22(1): 84-91.

7. Gotz F, Verheij HM, Rosenstein R (1998) Staphylococcal lipases: molecular characterisation, secretion, and processing. Chem Phys Lipids 93(1-2): 15-25.

8. Rollof J, Normark S (1992) In vivo processing of Staphylococcus aureus lipase. J Bacteriol 174(6): 1844-1847.

9. Hedstrom SA (1975) Lipolytic activity of Staphylococcus aureus strains from cases of human chronic osteomyelitis and other infections. Acta Pathol Microbiol Scand B 83(3): 285-292.

10. Buttke TM, Cuchens MA (1984) Inhibition of lymphocyte proliferation by free fatty acids. II. Toxicity of stearic acid towards phytohaemagglutininactivated T cells. Immunology 53(3): 507-514.

11. Eftimiadi C, Buzzi E, Tonetti M, Buffa P, Buffa D, et al. (1987) Short-chain fatty acids produced by anaerobic bacteria alter the physiological responses of human neutrophils to chemotactic peptide. J Infect 14(1): 43-53.

12. Eftimiadi C, Tonetti M, Cavallero A, Sacco O, Rossi GA (1990) Shortchain fattyacids produced by anaerobic bacteria inhibit phagocytosis by human lung phagocytes. J Infect Dis 161(1): 138-142.

13. Eftimiadi C, Valente S, Mangiante S, Mangiante PE, Niederman R (1993) Short chain fatty acids produced by anaerobic bacteria inhibit adhesion and proliferation of periodontal ligament fibroblasts. Minerva Stomatol 42(11-12): 481-485.

14. Hawley HP, Gordon GB (1976) The effects of long chain free fatty acids on human neutrophil function and structure. Lab Invest 34(2): 216-222.

15. Shryock TR, Dye ES, Kapral FA (1992) The accumulation of bactericidal lipids in staphylococcal abscesses. J Med Microbiol 36(5): 332-336.

16. Rollof J, Braconier JH, Soderstrom C, Nilsson-Ehle P (1988) Interference of Staphylococcus aureus lipase with human granulocyte function. Eur J Clin Microbiol Infect Dis. 7(4): 505-510.

17. Rollof J, Vinge E, Nilsson-Ehle P, Braconier JH (1992) Aggregation of human granulocytes by Staphylococcus aureus lipase. J Med Microbiol 36(1):52-55

18. Brunner H, Gemmel CG, Huser H, Fehrenbach FJ (1981) Chemical and biological properties of Staphylococcus aureus lipase. In: Staphylococci and Staphylococcal infections. Jeljaszwicz J, eds. Stuttgart. Gustav Fischer Verlag: 329-334.

19. Tyski S (1981) Staphylococcal lipase: purification and some properties. In: Staphylococci and Staphylococcal infections. Jeljaszwicz J, eds. Stuttgart: Gustav Fischer Verlag: 229-42.

20. Simons JW, Adams H, Cox RC, Dekker N, Gotz F, et al. (1996) The lipase from Staphylococcus aureus. Expression in Escherichia coli, large-scale purification and comparison of substrate specificity to Staphylococcus hyicus lipase. Eur J Biochem 242(3): 760-769.

21. Tyski S, Hryniewicz W, Jeljaszewicz J (1983) Purification and some properties of the staphylococcal extracellular lipase. Biochim Biophys Acta 749(3): 312-317.

22. Sakinç T, Kleine B, Gatermann SG (2007) Biochemical characterization of the surface-associated lipase of Staphylococcus saprophyticus. FEMS Microbiol Lett 274(2): 335-341.

23. Clyne M, De Azavedo J, Carlson E, Arbuthnott J (1988) Production of gamma-hemolysin and lack of production of alpha-hemolysin by Staphylococcus aureus strains associated with toxic shock syndrome. J Clin Microbiol 26(3): 535-539.

24. Murakami K, Minamide W, Wada K, Nakamura E, Teraoka H, et 
al.(1991) Identification of methicillin-resistant strains of staphylococci by polymerase chain reaction. J Clin Microbiol 29(10): 2240-2244.

25. Brakstad OG, Aasbakk K, Maeland JA (1992) Detection of Staphylococcus aureus by polymerase chain reaction amplification of the nuc gene. J Clin Microbiol 30(7): 1654-1660.

26. Johnson WM, Tyler SD, Ewan EP, Ashton FE, Pollard DR, et al. (1991) Detection of genes for enterotoxins, exfoliative toxins, and toxic shock syndrome toxin 1 in Staphylococcus aureus by the polymwoerase chain reaction. J Clin Microbiol 29(3): 426-430.

27. Suzuki N, Fuse A (1981) A UV-sensitive human clonal cell line, RSa, which has low repair activity. Mutat Res 84(1): 133-145.

28. Fernandez-Patron C, Castellanos-Serra L, Rodriguez P (1992) Reverse staining of sodium dodecyl sulfate polyacrylamide gels by imidazole-zinc salts: sensitive detection of unmodified proteins. BioTechniques 12(4): 564-573.

29. Towbin H, Staehelin T, Gordon J (1979) Electrophoretic transfer of proteins from polyacrylamide gels to nitrocellulose sheets: procedure and some applications. Proc Natl Acad Sci U.S.A 76(9): 4350-4354.

30. Nishimura H, Takao T, Hase S, Shimonishi Y, Iwanaga S (1992) Human factor IX has a tetrasaccharide O-glycosidically linked to serine 61 through the fucose residue. J Biol Chem 267(25): 17520-17525.

31. O’Reilly M, Dougan G, Foster TJ, Arbuthnott JP (1981) Plasmids in epidermolytic strains of Staphylococcus aureus. J Gen Microbiol 124(1): 99-107.

32. Lee CY, Iandolo JJ (1986) Lysogenic conversion of staphylococcal lipase is caused by insertion of the bacteriophage L54a genome into the lipase structural gene. J Bacteriol 166(2): 385-391.

33. Bradford MM (1976) A rapid and sensitive method for the quantitation of microgram quantities of protein utilizing the principle of protein-dye binding. Anal Biochem 72: 248-254.

34. Khouri MR, Huang G, Shiau YF (1989) Sudan stain of fecal fat: new insight into an old test. Gastroenterology 96(2 Pt 1): 421-427.

35. Tyski S, Tylewska S, Hryniewicz W, Jeljaszewicz J (1987) Induction of human neutrophils chemotaxis by staphylococcal lipase. Zentralbl Bakteriol Mikrobiol Hyg A 265(3-4): 360-368.

36. Braconier JH, Rollof J (1991) Influence by staphylococcal lipase on granulocyte metabolism and killing of bacteria. Zentralbl Bakteriol 276(1): 68-72.

37. Izdebska-Szymona K, Tyski S, Drela N, Sobiczewska E, Laskowska M, et al. (1992) Staphylococcal lipase affects phagocytosis of Staphylococcus aureus by human granulocytes and monocytes. Acta Microbiol Pol 41(1-2):49-56.

38. Rollof J, Hedstrom SA, Nilsson-Ehle P (1987) Lipolytic activity of Staphylococcus aureus strains from disseminated and localized infections. Acta Pathol Microbiol Immunol Scand B 95(2): 109-113.

39. Christensson B, Fehrenbach FJ, Hedstrom SA (1985) A new serological assay for Staphylococcus aureus infections: detection of IgG antibodies to $S$. aureus lipase with an enzyme-linked immunosorbent assay. J Infect Dis 152(2): 286-292.

40. Hu C, Xiong N, Zhang Y, Rayner S, Chen S (2012) Functional characterization of lipase in the pathogenesis of Staphylococcus aureus. Biochem Biophys Res Commun 419(4): 617-620. 